\title{
A CASE REPORT OF WEGENER'S GRANULOMATOSIS
}

\section{By}

Tsutomu HANADA M.D. and Yasuo WATANABE M.D.

From the Department of Oto-Rhino-Laryngology Osaka University Medical School (Prof: T. Hasegawa)

A case of Wegener's granulomatosis in 37 yearold male was reported. The patient died due to respiratory failure after one year from the onset.

Remarkable clinical findings were exophthalmus, voluminous crust accumulation in nasal cavity, fever, shadow on chest $X$-ray suggesting pulmonary tumor, accelerated BSR and increase of serum $\gamma$ globulin. The findings suggesting nephrotic complication were unremarkable.

Presence of bronchial asthma and chronic sinusitis in past history, alluded to the possible relationship of these diseases to Wegener's granulomatosis.

The patient had tonsillectomy in the past. It seems that a further investigation should be made as to the relationship of tonsillectomy and thymo- lymphatic system to the etiology of the rare disease, though it has been hardly referred to in the literature.

In regard to the treatment, $\mathrm{Co}^{60}$ irradiation, long-term administration of steroids and carcinostatic agents more or less brought about symptomatic relief, while autovaccinization with staphylococcus aureus cultured from intranasal crusts was found to be ineffective.

The autopsy revealed necrotizing granulomatous lesions in nasal cavity, orbita, upper and lower respiratory tract, lung, and skin.

Microscopically, angitis and thrombus were found in the lesions of respiratory tract, lung and skin.

\section{Wegener 氏肉芽腫症の 1 剖検例}

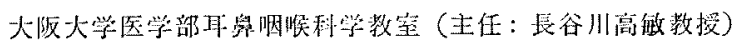

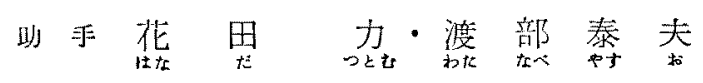

\section{緒言}

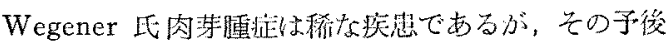
の極めて不良な点に颃いて，また，その病园の不明な点 に和いて，近年注目されてきた。

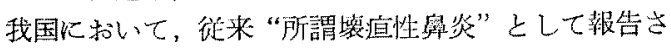
れていたものの中には，率腔，口蓋等のみを犯す局所疾

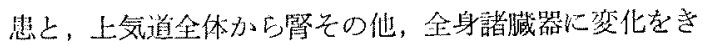
たす疾患达包括さ机ていたが，1937年のWegener の 報告以来，後者学1 つの独立疾㭧として报ら傾问が世界 的になり，本邦に打いても，近年 Wegener 氏肉苏腫 症としての垠告をみるよらになつた。(一以下“氏”を 略与。一

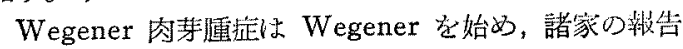

するように，鼻拉よび肺，㫮その他の諸淢巤に血管炎， 肉芽形成を主とした変化をきたす。

疾患の因関しては，フレルギー説，賿原病説，他疫

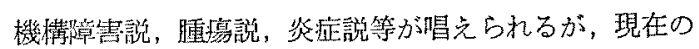
処，未だ解明されていない，今回，私期比校的早期に

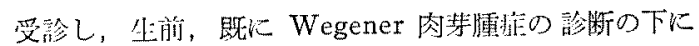

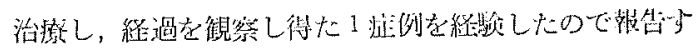
る。

〔症例〕

热 者 S.F. 37才含 職業 会社員

初讋炤和39年1月27日

主 訴 两視力障害，発熱，血性舅漏，頭痛 


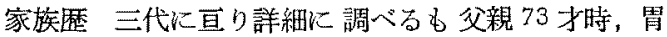
潰瘍にて死亡。妹 1 人, 慢性副㑭腔炎の他特になし.

既往歴 4 才㭙，急性腹膜炎の疑いで入院治療.

10 才㭙，習慣性屚桃腺桨にて扁佻剔出術をうける。

12 才時, 乾性助膜炎.

20 才時迄，気管支喘息あり。

36 才時（昭和 38 年 4 月より）肺結核の疑いにて12月 迄三者併用療法を5け治癒.

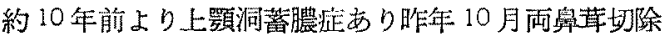
術をらけた。

赀好品 型草 20 本/日 性格・神経質 酒 (少々) 性病 否定 出血傾向 (一), 両親伹緑 (一)

【現 病 歴)

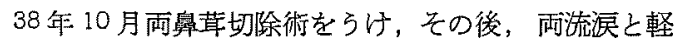
い視力減退，舅出血の頻発があつた。

12月末上り徽熱が綕き，某病院内科にて 湖絬核の再 発ではないかとして1月18日より入院し，諸検查の結 果, 否定された。しかし1月21日，突然に両視力減退 著明となり（R.V.=O，L.V.=0.2）頭痛を伴つてきた。 弛張熱が綕いた。

1 月 27 日，当院耳鼻科に紹介され入院す。

\section{[入院時所見]}

体格 中等度 栄咅 中等度

脈搏 $72 /$ 分 整 緊張 良

血化（右） $146 \sim 88 \mathrm{mmHg}$

呼吸 胸腹型 $16 /$ 分 整

眼球結膜 軽度盆血望

胸部 打聴診共に異常なし

表在リンパ腺

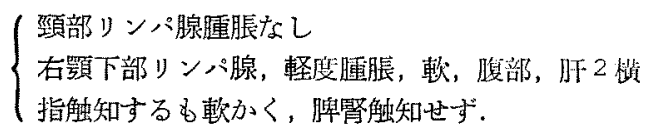

焗所々見〕

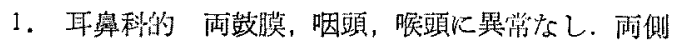

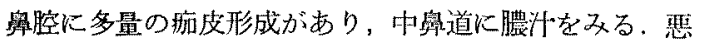
臭（酸つぱいよ5な，やや刺㦸性ある）あり。

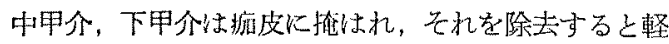
度の出近あり。

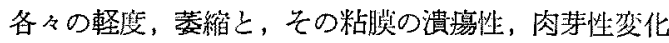
を东る。

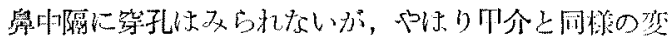
化をみる。
2. 眼科的（眼科初䥻日，1月29日）
R.V. $=0$
L.V $=0.1(\mathrm{~m}, \mathrm{C})$

瞳 孔維 正常

刘孔区射 右 直接 (一) 間接 (t)

左 直接 $(\boldsymbol{t})$ 間接 (一)

湌影法
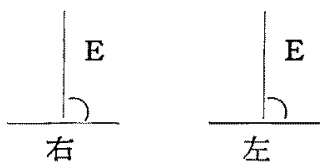

中閌透光体 罢常なし

眼底 右側，乳頭が軽度に充Ifr.

左側, 正常

視野 右: 測定不能

左：ほぼ正常

眼球突出 ヘルテル眼球突出棓什にて

右: $14 \mathrm{~mm}$ 左: $14 \mathrm{~mm}$

眼圷 異常なし

眼球連動 軽度幥害 (下記)

3. 袖経科的

両眼球突出著明. 雨眼瞼浮腫著明. 两眼瞼下垂. 両三 又神経枝，王痛あり。

眼球運動は右側にて外旋障害あり。

两側共上下方向の軽い運動障害あり，沓た，两側共， 内唄人の軽度の運動障害方り。

対孔反射 值接反応が右側消失，左側正常。

瞳孔形，左右同 し円型

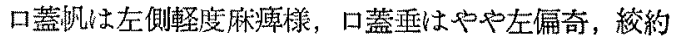
区射消失, 舌連德異常なし。

咬能反射正常, 顔面感覚正常, 顔面神経麻痻なし, 前 腕反射户驹.

膝蓋腱反射正，アキレス腱反射正

ハシビンスキ一反射 (一)

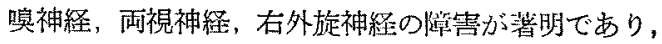
それも末梢性の烌化のみである，非枢性の神経障害はみ られない.

\section{〔諸榆查成績〕}

1) 近液一般検查 $(27 / 1)$ 赤血球 $411 \times 101 / \mathrm{mm}^{3}$. $\mathrm{Hb}: 80 \%$. $\mathrm{Ht}: 36 \%$ 血小板 $25.4 \times 10^{4} / \mathrm{mm}^{3}$

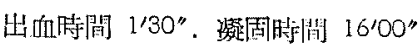
扎淮型 $\mathrm{O}$ 悡. 毛爬球 $12800 / \mathrm{mm}^{3}$ 
St.

Seg

Eosino.

Baso.

Lympho

Mono.

赤血球沈降速度

1 時間值 $74 \mathrm{~mm} 2$ 洔問 $105 \mathrm{~mm}$ ブラスミン活性 (一)

2) 血液化学 $(18 / \mathbb{I})$
Ca. $5.2 \mathrm{mEq} / l$
Na. $137 \mathrm{mEq} / l$
$\mathrm{Cl} 99.0 \mathrm{mEq} / l$
K. $5.0 \mathrm{mEq} / l$

3) 骨娟像 $(22 / 1)$

有核細胞数 $25 \times 10^{4} / \mathrm{mm}^{3}$

白血球系/赤血球系 4.5

第 1 表 Wegener 肉芽腫症の臨床症状 (Walton)

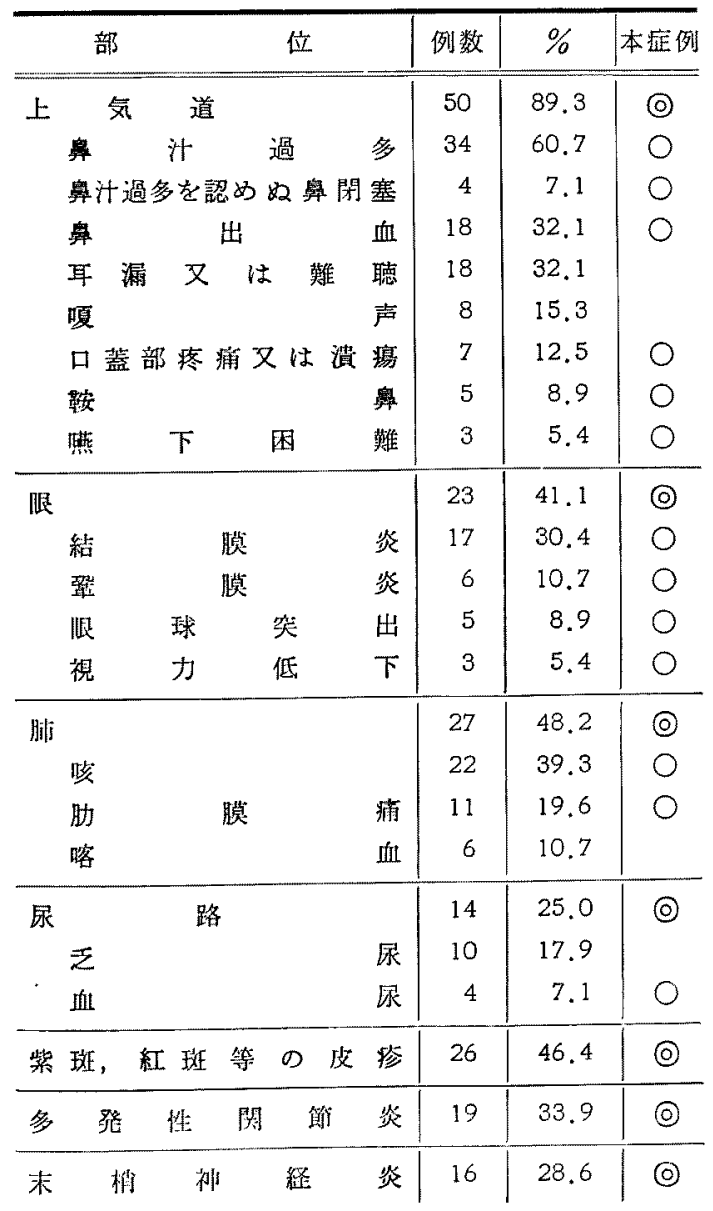

4) 尿検查 $(11 / \mathrm{V})$

色調 橙黄色, $\mathrm{pH}: 5.5$ 比重: 1,025

蛋白（一） 糖（一）ウロビリノーゲン: 正常

赤血球 $(-)$ 白血球 $3 \sim 1 \sim 2 \sim 6$

上皮細胞 $(-)$ 円柱 $(-)$ 修酸塩結晶 $(t)$

5) 検 便

ビリルビン (一), ウロビリノーゲン（+）

潜血反応 ベンジジン $(-)$, 等生虫 $(-)$

6) 肝機能検查 $(11 / V)$

I.I. 5. B.S.P. $5 \%$ Cobalt. Ro

Kunkel $12 \mu$. G.P.T. $20 \mu$

Alkaline Phosphatase $1.9 \mu$

第 2 表 Wegener 胸芽腫症の梌查所見 (Walton)

\begin{tabular}{|c|c|c|c|c|c|}
\hline 检 & 查 & 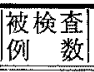 & $\begin{array}{l}\text { 翼常 } \\
\text { 例数 }\end{array}$ & $\begin{array}{l}\text { 霬常 } \\
\%\end{array}$ & 本症 \\
\hline \multirow{2}{*}{ 旂ントゲン } & 頭篕・副鼻腔狯影 & 21 & 18 & 85.7 & 0 \\
\hline & 肺陰影 & 40 & 38 & 95.0 & 0 \\
\hline \multirow{3}{*}{ 血 液 像 } & 小赤血球性 坌 血 & 33 & 32 & 97.0 & \\
\hline & 白 血 球 增 多 & 56 & 38 & 67.9 & \\
\hline & 好 酸 球 增 多 & 37 & 17 & 45.9 & \\
\hline \multirow{2}{*}{ 的液生化学 } & 残 余窒溸增加 & 27 & 23 & 83.2 & \\
\hline & 高グロブリン血症 & 10 & 8 & 80.0 & 0 \\
\hline \multirow{4}{*}{ 艮 } & 蛋 白 尿 & 42 & 37 & 88.0 & 0 \\
\hline & （赤血球 & 42 & 34 & 81.0 & 0 \\
\hline & 沫浩 白血球 & 42 & 21 & 50.0 & \\
\hline & (m 柱 & 42 & 28 & 66.5 & \\
\hline 高 & 正 & 33 & 8 & 24.0 & \\
\hline 赤 & 促 & 10 & 9 & 90.0 & 0 \\
\hline
\end{tabular}

第 3 表 血消蛋白電気泳鄅

\begin{tabular}{c|c|c|c}
\hline & $28 / \mathrm{I}$ & $14 / \mathrm{V}$ & $23 / \mathrm{Vl}$ \\
\hline \hline T.P. & $6.3 \mathrm{gr} / \mathrm{dl}$ & $6.6 \mathrm{gr} / \mathrm{dl}$ & $6.8 \mathrm{gr} / \mathrm{dl}$ \\
\hline Al. & $54.9 \%$ & $49.2 \%$ & $20.7 \%$ \\
\hline$\alpha_{1}$-Globulin & 3.3 & 4.1 & 8.9 \\
$\boldsymbol{\alpha}_{2}$-Globulin & 9.8 & 12.7 & 19.1 \\
$\boldsymbol{\beta}$-Globulin & 14.1 & 13.7 & 15.6 \\
$\boldsymbol{\gamma}$-Globulin & 17.9 & 20.3 & 35.7
\end{tabular}


7) 血消学的检查

$$
28 / 11 \quad 14 / \mathrm{V} \quad 23 / \mathrm{H}
$$

Total Protein $6.3 \mathrm{gr} / \mathrm{dl} \quad 6.8 \mathrm{gr} / \mathrm{dl} \quad 6.6 \mathrm{gr} / \mathrm{dl}$ Al $\quad 53.9 \% \quad 49.2 \% \quad 20.7 \%$ $\alpha_{1}-\mathrm{Gl} . \quad 3.3 \% \quad 4.1 \% \quad 8.9 \%$ $\begin{array}{llll}\alpha_{2}-\mathrm{G} 1 . & 9.8 \% & 12.7 \% & 19.1 \%\end{array}$ $\begin{array}{llll}\beta-G 1 . & 14.1 \% & 13.7 \% & 15.6 \%\end{array}$ $\begin{array}{llll}\gamma-\mathrm{Gl} & 17,9 \% & 20.3 \% & 35.7 \%\end{array}$

紬数数 $7 / 3$

総蛋白 $0.19 \mathrm{mg} \%$

W.R.(一)，Tryptophan 区心 (一)，精 $70 \mathrm{mg} / \mathrm{dl}$ クロール $129 \mathrm{mEq} / l$

11) 算機能検查

$$
\text { 濃縮試嗝 } 1030 \text { P.S.P. } 46 \%
$$

12) レントゲン検查 $(29 / 1)$

胸部：現在進行怪病变を热如ず。

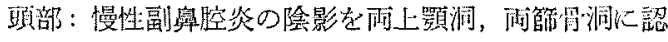

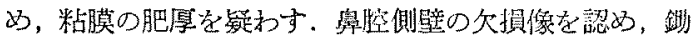

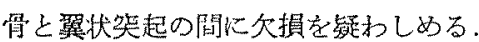

頭部断曆撮影，箸变なし。

13) 腰䧴穿制所見

液E 230〜120 $\mathrm{mmH}_{2} \mathrm{O}$ ノンネ・アペルト(一)

䋉蛋白 $0.19 \mathrm{mg} \%$

細胞数 $7 / 3$, 精 $70 \mathrm{mg} / \mathrm{dl}$, Cl $129 \mathrm{mEq} / \mathrm{l}$

\section{【人院袮経過】}

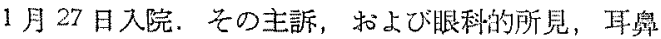
科的所見より，一応，學性の視神経炎の疑い,て1月31 日，上颚洞閉放，上顎括上び節骨洞の根治手術を行万。

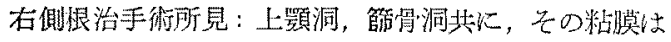

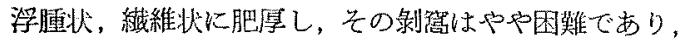
洞の内容は獎液㴍で，泇皮の粘点八の附着がス口れ，や や強い臭気があつた，術中の出血络通常の蓄脿手術より 少かつた，富控骨側壁は欠損し，恰か子対孔が大きく， 既にあけられているかの如きであらた。柴形骨洞粘膜も 同様の病变で病的粘膜を除去した。洞内の骨壁は全体と

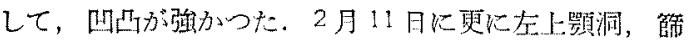
算洞根治手衔老行つた。

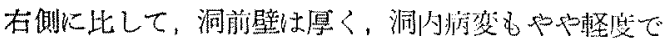

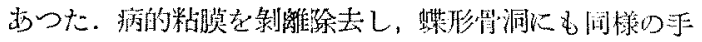

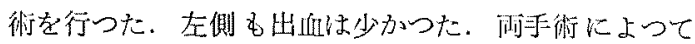

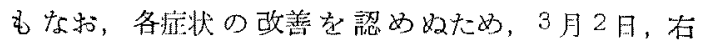

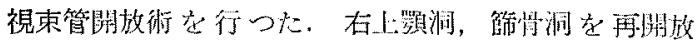

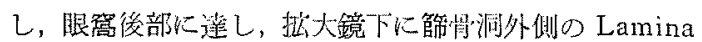

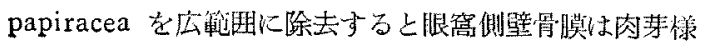

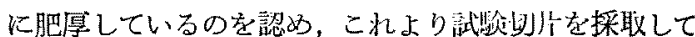
術を終つた。

視束管は解剖学的関係から開放するに到らなかつた。 上記手術時埰取組織の所見 (写真 6,7$)$ は, 全体として

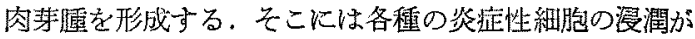
認められる。即ち，帓中球，リンパ球，形質細胞等を認 \$市.

唯これいらのれは形質細胞より大型で核の大きい原 北貿の好塩基性の細胞を認める。

また因芽細胞の一部は細網細胞様で增殖を示し，巨細 胞和よび異型性を示す。

填死巢，線維化等を認めるが，血管の類線維素性变 性, 買死性の要化は認められない。

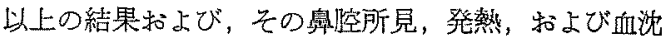
值の促焦よりWegener 肉莱蕾方培えられたが，尿所

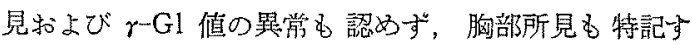
べき乎のなく一応, malignant granuloma (lethal midline granuloma) との移行型，なたは Wegener 肉陦腫の初期かと考々，プレドニン $30 \mathrm{mg}$ 内服，抗生 物筫 (アイロゾン，テラマイ筞）フリナミン F 150mg チトクロームC，レチゾール，7\%重曹水，プレドニン 球後注射，コーデルゾール球传注射等を行い，経過観察 与るに，番腔内所見，血沈値等，一進一退，発熱8 38.0 $\sim 39.0^{\circ} \mathrm{C}$ の弛張熱むり，眼球突出著明 $(24 \mathrm{~mm})$ となり 眼球運動にも障害をきたし，更に乳頭にも变化をきたし たので，3月50日，啊側上り球後部，上顎洞にコバル 卜照射を行万(総回数 30 回, 病举楾量 7100r) (写真 1 ,

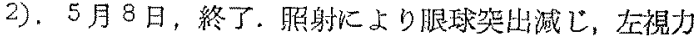
$(L . V .=0.6)$ 欧涪され，視野子改善される。

眼底所見，在側菱縮，左側，異常なし。

6 月，胸部レ線像（写真 4,5）にて存湖門部に蕾瘤陰

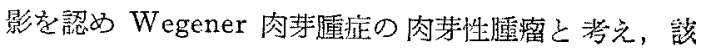
部代コバルト䀡射を開始す。

6 月 16 日，阔上腕部の注射部位に当る硬結部加境死

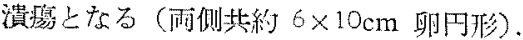

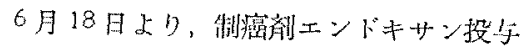

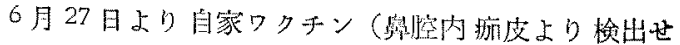
る Staphylococcus aureus の菌液上り作成) 14 回，

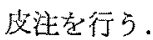

8月に入り，口唇部执よび顔面に皮疹，肚門周柬膿痘

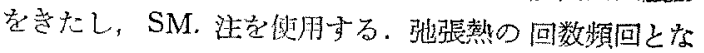

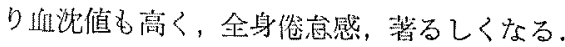

8 月中旬，数回，排尿時に血塊様凝固物を排出，9月 
写 真 1

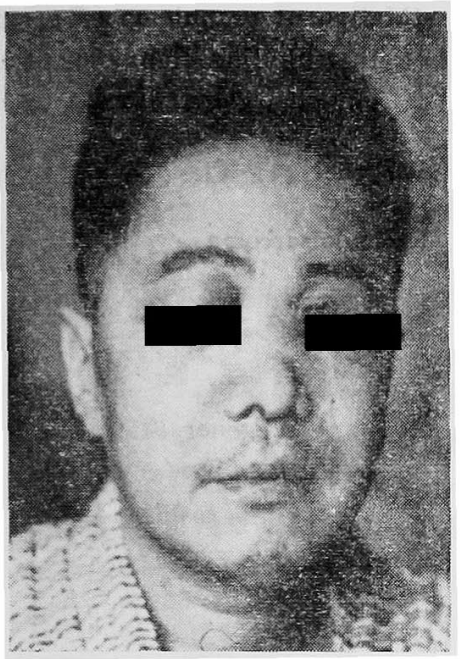

写真 4 胸 部 写 真

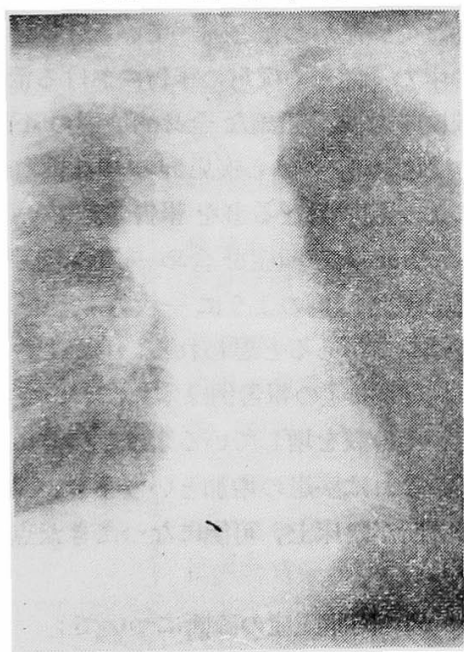

写真 6 舅腔内肉芽椂組織

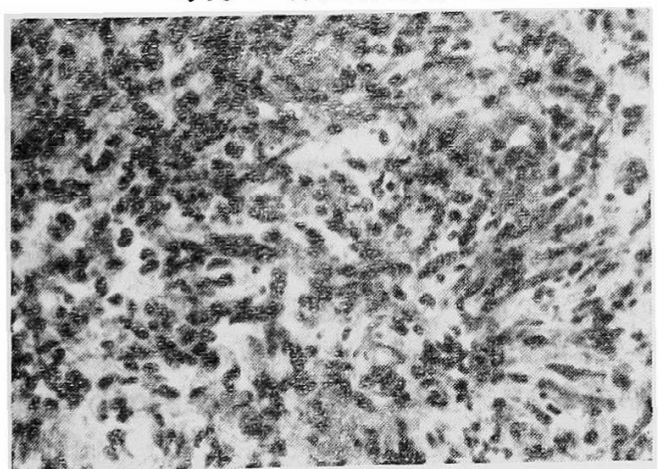

写真 2

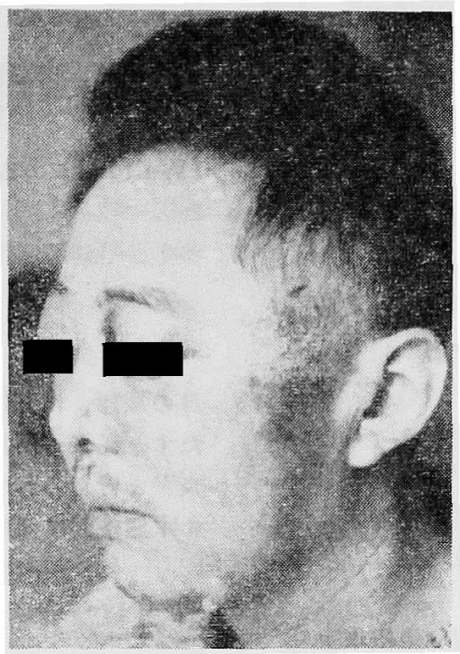

写真 3 上顎洞断層写真

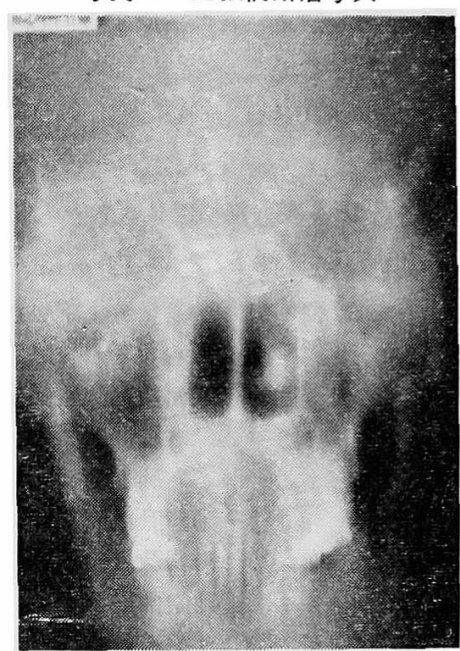

写真 5 胸部断層写真

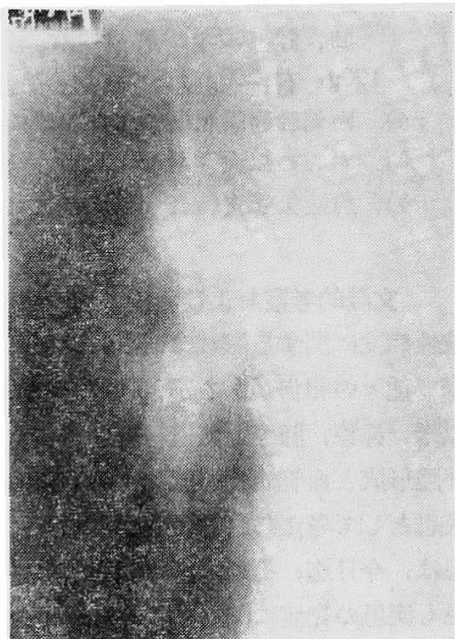

写真 7 節骨·洞附近肉芽様組織

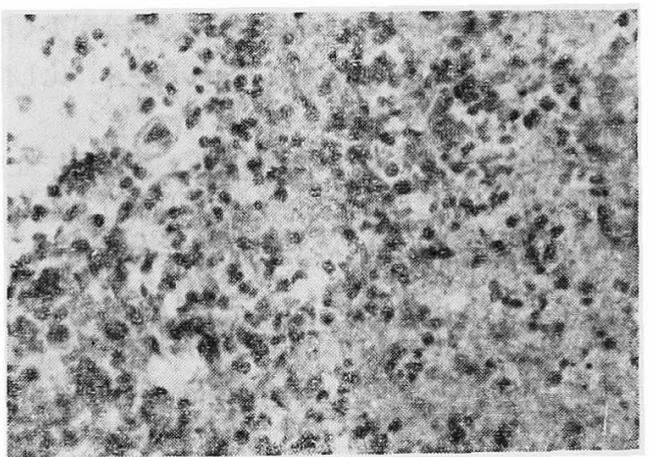




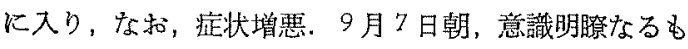
呼吸困難を訴光，各種治療するも急速に状熊悪化，午後 9 時半死亡一.

[剖検時所見]（第 4 表）

第 4 表 剖検所見（大阪大学第 1 病理）

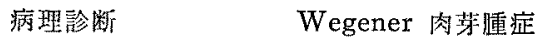

病変部位上気道下気道朋 (左 $780 \mathrm{gr}$ 右 $750 \mathrm{gr})$ 眼管皮墙

1) 壊死性肉芽性病変 右肺門部 $4 \times 5 \times 3 \mathrm{~cm}$ 右肺上葉 $4 \times 4 \times 3 \mathrm{~cm}$

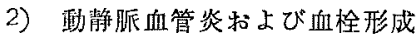

副 病 変 1) 両側肺慢性間質性線維症 肺胞内出血

2)リンパ節細網内皮細胞組織堌生 (左右肺門部，父管分岐部)

3) 全身諸葴器らつ血 腈, 肺 $1600 \mathrm{gr}$ 脾 $165 \mathrm{gr}$ 㹂, 石 $190 \mathrm{gr}$ 右 $200 \mathrm{gr}$ )

4)両側肺胸膜肥厚括よび線維性瘺着

5) 右心の拡大 $375 \mathrm{gr}$

6)急性気管支肺炎

\section{文献的考察および考按}

鼠腔の䍗逭性病変に関する記載は Mc. Bride (1896) が行つて以来，種々の報告があるが，1937年 Wegener が報告して以来，鼻腔，肺等上気道，腎和よび，その优

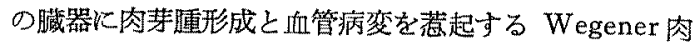
芽腫は，一疾虫として考光られるよらになつた、しかし ながら該惶恵は，今日迄，その本態は明らかにされず， 病理学的所塄も疾患の発症に関して，今一歩の処で，そ の明確な解明を与党て呉れない。

従来，耳鼻咽喉科領域では，所謂，塄㗐性瞢炎という 診断名の中に，この疾患の包括されていた場合が少くな く, 従つて, 本疾患の報告の数は, その発生率に比して 少なかつたと考克られる。

近年 Walton (1958，1959，1960) 性溹腔に裳死扣上 び肉芽性病変をきたし，治痛し難い疾患群 (本邦で彷

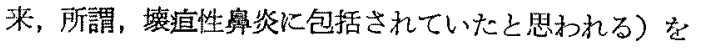
病理学的に分類し,

1) malignant granuloma 拉よび 2) Wegener 肉芽 腫症执よび 3) reticulum-cell sarcoma と3つに区分 した（第 5 表）。

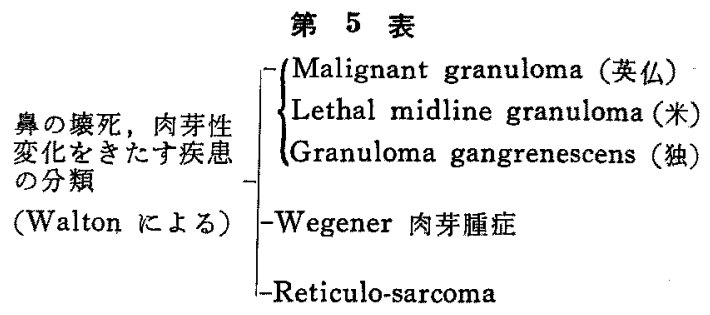

第 6 表

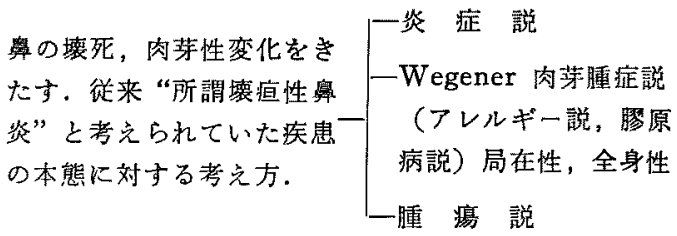

Walton によれば，これ等 3 者は外国においててb， しばしば混同され，従つて，その正確な剖検の統計的報 告が行われていなからたと述べている，切替教授も，そ の綜説の中で, 從来の疾患の報告に打ける治潦中の経過 および剖检時の充分正確な全身的検案の不足を指摘さ れ，北村教授も，これら疾患群の病理標本の診断看 理学者により 種々異なる事を報告されているが，ここ にも Wegener 肉芽隀症を含め一連の肉芽尰疾患の猃 断が，他の悪性腫痬の上らに一枚の病理標本で片付け られない難しさがあると思われる，しがながら，近年 Wegener 肉芽腫症の報告例は本邦においてる，外国に 虬いても，その数を增している事は学会誌により明らか であるが，これは疾患の增加といらより，Wegener 肉 苯凬症の診断が臨床上，可能になつてきた点にも一因が あると思われる。

Wegener 肉节腫症の診䉼について:

Wegener 肉芽腫症は, 前述の如く, その病里組織像 による分類もなお，種々の異つた見解があるたる，その 䛦断は難しい.

臨床的にも，その初発症状は，鼻閉，鼻漏等，鼻泟状 を主訴とする場合の他，下気道に主な病変を有する場 合，また，幾道以外の繁，脾等諸蔵器の病変が主である 場合さらに眼球突出視打障害索伴ら場合等，種々なる様 相呈呈する，その上，その好発年令，性別む，特異的な ものでなく，従つて，その鑑別診断は極めて難しい， 说来，本邦で用いられていた“所謂買迫性鼻炎”という 病名は，上記，各疾患（悪性肉芽腫，細絧肉䢮）を包括 して怙り，極めて便利であつたが，これは Waltonの 
分類するように，前还 3 者に（第 5 婊）に分類する万が 疾患の解明への上に好交しいと思はる。.この事唗従来， 耳科の報告が，全身的椧索に尔ける処があつたという事 だけでなく、病理所見の正当な解积のためにも必要であ ると考克る。

鼻の細網肉腫症は一回の病理組織像の検索に叔いて疾 患の崄断が決定される事が少く，また北村等の報告する 上うに同一の標本る病理学者に上り判断が異なるを稀上 しない.

しかしながら組織標本に执いて，肉腫所見を認める上 は、これを病理学的に一つの単一疾患であると考えるの が正しいと考党る。

私共は最近, 本症例とは別に，4年有余に互り経過し た覀性肉茅腫 1例を経験したが，との剖検所見において
も，瑟性肉芽揰 (Walton による)は Wegener 肉芽腫 と较べて，(臨床像に比して）病理的所見に乏しい，私 共俚この両者が 同一疾患であるといら考克に反対する べき豊かな経駼を持たないが Walton が説える如く， 病因の解明される時迄，この両者を区別して考穴たい， Walton Kよる雨疾患の鑑別点の記載を引用して第 7 䨿 に示す.

これら雨疾㭧はその予後の不良なる点に打いて著るし く私共の関心をひきつけるのであるが，夲の既往厢，家 族歷儿特記すべきるのは認められない，Schmalixは Wegener 肉芽腫症に結核性病変が先行するとし，Stewart は鼻疾患が先行するといらが，これらは全ての症 例に当てはまらない。

私共の症例比いて你発病 1 年前飞某病院比て肺絬核

第 7 表

\begin{tabular}{|c|c|c|c|c|}
\hline & & & Wegener 肉芽腫症 & Malignant Granulomata \\
\hline 年 & & 令 & $17 \sim 75 \quad$ 平均 44 & $11 \sim 69$ \\
\hline & 性 & & 男：女：6 & 男：女 \\
\hline 既 & 往 & 整 & 副番空炎，気管支炎が 7\%に & 副絪腔炎が16\%に認められる \\
\hline 発 & & 病 & $\begin{array}{l}\text { 鼻括よび肺莚状 } \\
\text { 全身状熊不良 }\end{array}$ & $\begin{array}{l}\text { 睤症状のみ } \\
\text { 全身状態良好 }\end{array}$ \\
\hline 局 & 所 病 & 変 & 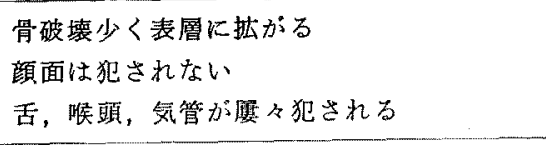 & $\begin{array}{l}\text { 広沉な骨破壊 } \\
\text { 顔面を犯す場合が70\% } \\
\text { 舌，中耳，唉頭，気管は犯されぬ }\end{array}$ \\
\hline 経 & & 過 & $\begin{array}{l}6 \text { カ月又はそれ以内 } \\
\text { 急激火增悪 } \\
\text { 広沉な炎症症侯 }\end{array}$ & 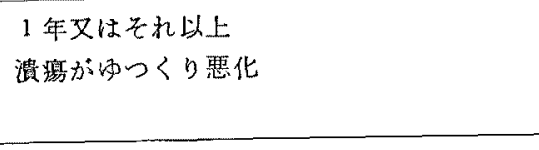 \\
\hline 転 & & 㠗 & 腎，呼吸，心疾飞て死亡 & 肺炎，脳膜炎，出血による \\
\hline 肺の & レントゲ: & & 多数の円形陰影 & 時に肺焱 \\
\hline 血 & 液 & 像 & $\begin{array}{l}\text { 好酸球增多, 震々あり } \\
\text { 小細胞性蔶血 }\end{array}$ & $\begin{array}{l}\text { 好酸球增多なし } \\
\text { 貧血 も稀 }\end{array}$ \\
\hline & 液 化 & 学 & 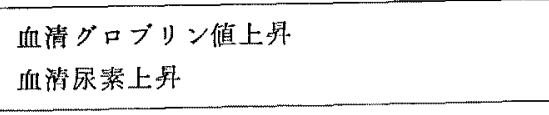 & $\begin{array}{l}\text { 血清グロブリン正常 } \\
\text { 血清尿潆正常 }\end{array}$ \\
\hline & 尿 & & アルブミン $(+)$, 細胞 $(+)$, 冈柱 $(+)$ & 正常 \\
\hline 生 & & 检 & $\begin{array}{l}\text { 巨細胞性肉芽腫 } \\
\text { 泡状組耭球。好酸球增多 }\end{array}$ & 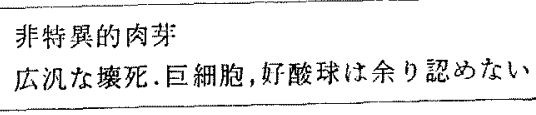 \\
\hline 剖 & & 梌 & 后沉な肉第性病変，血管病変 & $\begin{array}{l}\text { 肺炎, 腷膜炎 } \\
\text { 他に敗血症病变をみるのみ }\end{array}$ \\
\hline
\end{tabular}




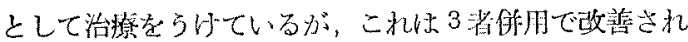
た。

来院時には胸部 X 線像で進行性の病変を認めず入院 後 4 力月にて肺門部に雷瘤状陰影をきたした，说つて， その時間的な関係より結核が先行するといら考兑は否定 できないが，Wegener 肉芽朠症，そのるのが結核と直 接関保があつた之断定する根拠を掓たない。

家族歷甧に結核患者の多い家系ではなく，他にも变 化は認めない。

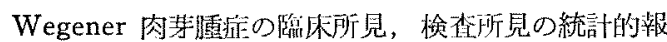
告に関しても Walton の記載が最も詳細であり，これ を，私共の症例の所見上比較のため，引用すると，第1 表，筧2表の如くなる。

この場合，注意を要することは，その発現率の見方で ある、疾患の全経過に亘って忠笑に症状の経過を記録し たか，また梌索を行つたかどらかが関係する。

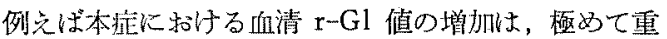
要であるが私共の症例では疾患の初期にはその增加は余 り著るしくなく，その後，潮次 r-Globulin 值の上景を きたした。

同様の事は腎機能，尿所見に就いても考兄られ，即 ち，本症例で末期偻度血尿の上らな訴党があつたが尿 検索時には異常所見を認めなからた。経過が長くなれば 蛋白杘，残余堂素の增加をきたしたのではないかと思わ れる。

このよらな意昧に打いてる Wegener 肉苏腫症の初

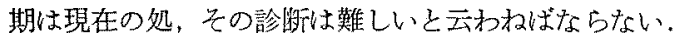

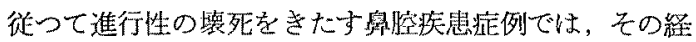
過老公分観察すると同時に，各種，全身検查（血沈，血

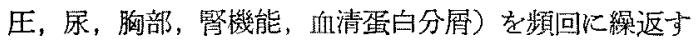
要があると思われる。

試験切片の病理的所見について：

診断の最名有力な因子となる病理学的所見化関して Wegener の原著によれば，上気道殊に鼻腔，副䰨腔， 䐅頭等に肉芽遥形成が著るしく他の㵴器にも，同様の肉

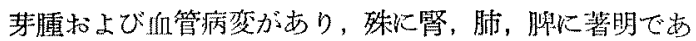

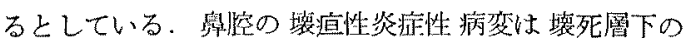
Fibroblasten に富んだ肉芽組穖上りなり肉芽は類上皮 細胞，組織球，抢上び，白仙球上りなり，各種の異物型 若しくは Langhans 型巨細胞が存在する。また病㤎の

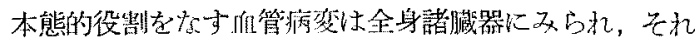
は結節性動脈周明炎と同様の小動脈の境死であり，それ は環状に内層㭙に中層に电あり(写真 $9 ， 10)$ 弾力膜の

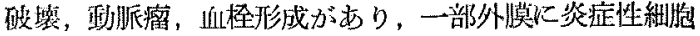
浸潤を認め，時には肉军形成や洀痕形成が血管外膜にも 及んでいる．血管内膜の增殖性肥厚も特巽で，血管内腔 が狭险となつている（写真 9，10）。

このような血管病変は上気道の他，全身諸蔵器飞る る られるが，一般に新鮮なものが多い，

罥にも，特異的な病変を認める．即ち，系球体の大部

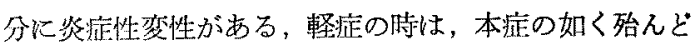
夜化を認めない場合すあるが（写真15)。内被細胞の核 の変化を認好る程度から，高度のものは毛細血管の均質

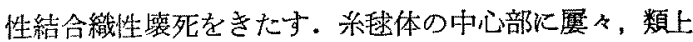
皮細胞やリンパ球，flbroplastin よりなる肉芽腫があ り，斯様な所見は従来の腎炎には全く認められず，この 意味からして肉莪腫性 毛正体腎焱と云うべき变化を呈 す。この他，脾にも変化を認めているが，大約すれば以 上 3 つ変化を認める場合，これをWegener 肉芽腫 症と考えて差支学ないと考克られている (Wegener, 石倉, 他).

しかしながら普通は鼾腔内組絒所見が最も採取され易 い点より第 1 の悬腔の組織所見の特異性より判断を要求 されることが少くない。

この組織学所見の判断は記载の如く，特異的なようで あるが，一枚の Haematoxylin-Eosin 染色では，前述 3つの疾患の分類は病理学者に叔いても見解を異にする 場合がある。

いづれにしても病理組織像は肉芽腫㧍よび血管炎であ るが，鼻腔組織の標本では，壤死組織および肉芽腫であ ることが多く，従つて悪性肉莱腯（Walton）との鑑別 は肉芽腫に認められる浸潤細胞によらねばならない。 Wegener 肉苯腫では Langhans 氏型および異物型巨 細胞，プラスマ細胞，好中球，リンパ球，好酸球，拉上 び類上皮細胞等の細胞浸潤があり，これ以上の変化を鼻 腔よりの組織切片では求め難い，従ってWalton の分 類するようにる者に分類するには鼻腔よりの組織切片だ けで忙不充分である，しかし血管炎は本疾患洔異的で ありこれは肉芽腫之は無関係に主に小動脈，細動脈，お よび小静脈文られ，急性期には壁全層の 類線維素変

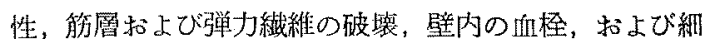
胞漫潤を示守。

初網肉腫症との鑑別の意味に挍いても，H-E 染色だ けでなく，銀染色を行らべきと洘える。初期に怙ける診 断は 1 校の病理標本だけでなく咟床症状，検查成績と共 に経過留意して行ら必要を感じる。 
真与 8 肺の壤死，肉讶性病変およびその周辺の血管炎

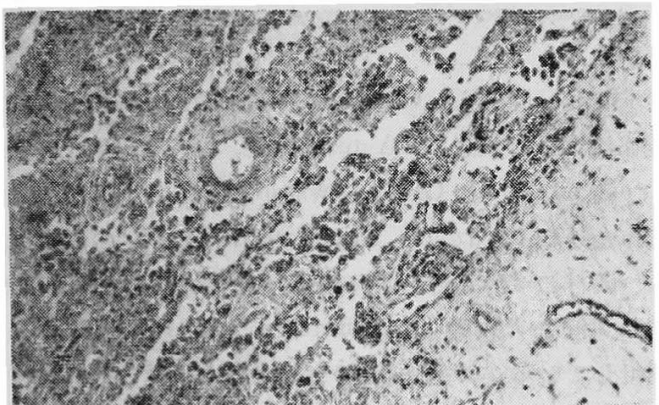

肺の壊死組織（左）とその周辺の血管炎

細胞浸潤，へモジデリン沈着 ○...

真写 10 肺の血管炎

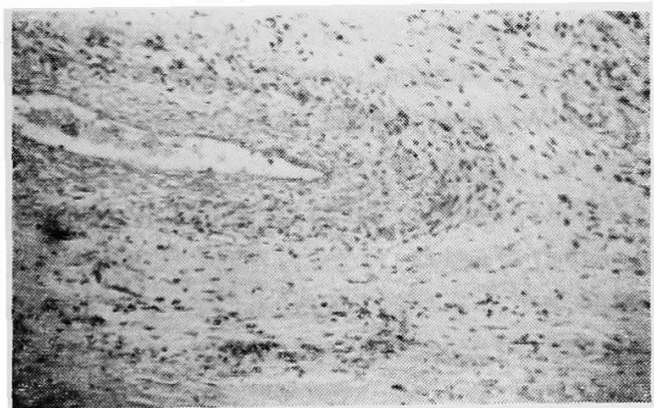

真写 12 眼窝肉芽中の巨細胞

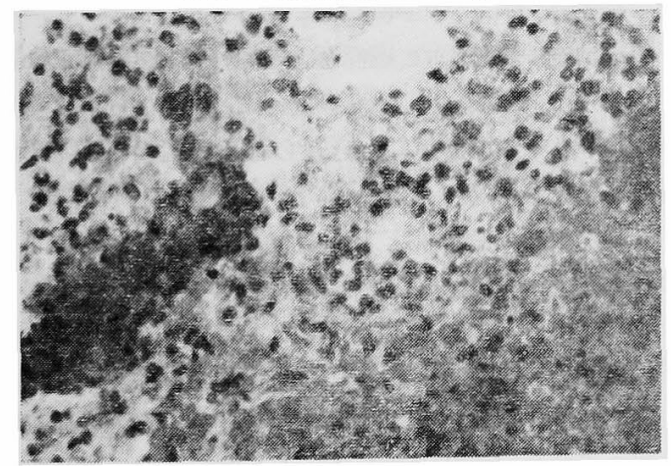

真写 14 飾骨組䋐の necrotizing angitis 及び giant cell

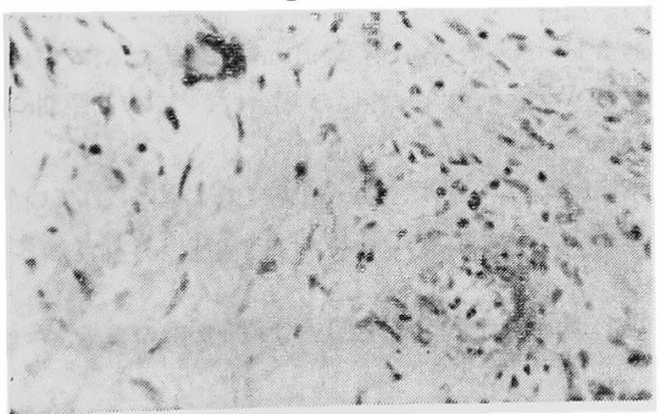

真写 9 帅の䖝管炎

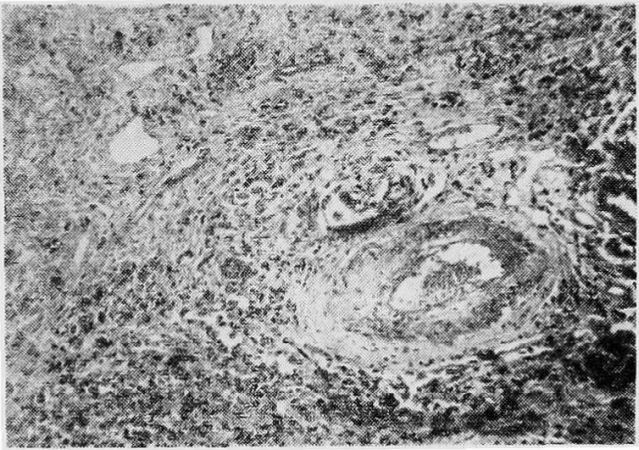

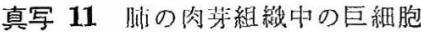

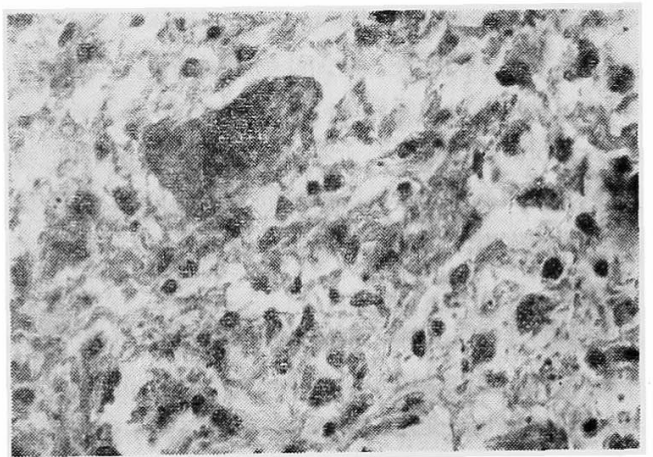

真写 13 潰瘍性皮䖉にみられた壊死組織 周辺の血栓形成拈よび巨細胞

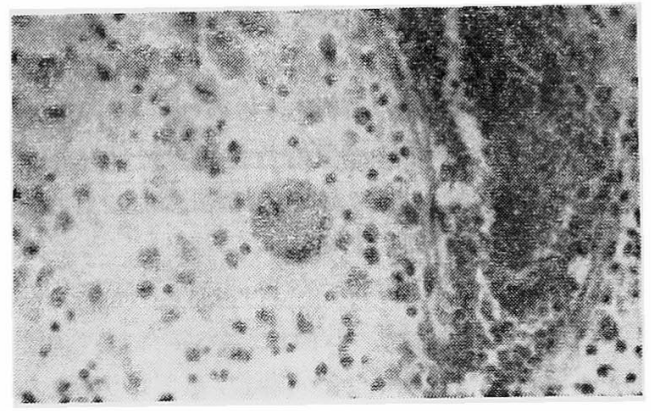

\section{真写 15 肾 組 絹}

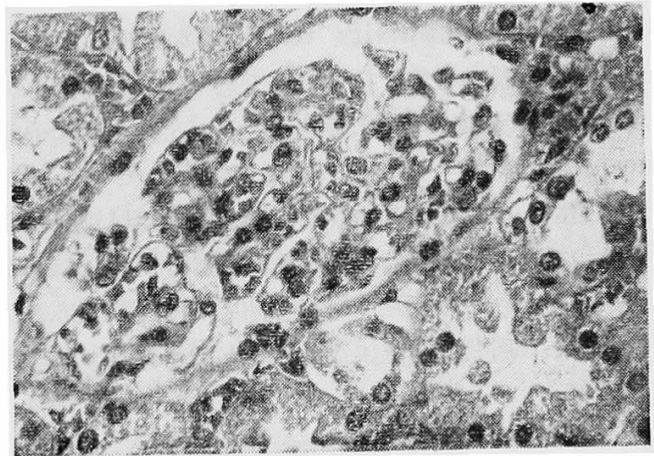




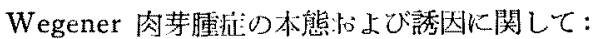

Wegener 肉芽腫拝の本㷫に関しては種々異つた見解 があるがな打不明である。

その病理組瀻像が Periarteritis nodosa に類似した 晌管炎を星することより Periarteritis nodosa の範腾

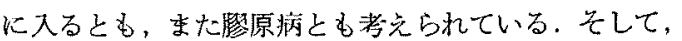
その発現は $\gamma$-Gl 值增加等より hyperimmunity とも 説明されている。

しかしながら Zeek u. Smith (1948) は剖検および 動物实験で，この雨者，即ち Periarteritis nodsa の血 管病変と hyperimmunity のそれとは差哄があるとし ている.

膠原病の統一観念は Klemperer (1950) がリウマチ 熱，リウマチ榚関節炎，結節性動脈周囲炎，エリテマト

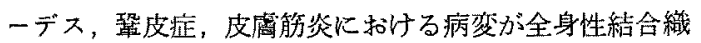
の fibrinoid 変性をきたするのであることを重視して唱 えたが Rössle (1937) は結合織の fibrinoid 変性はア レルギー性疾患に特徽的な形態的变化であると速へててい る.

Ehrlich (1952) は胗原病の病园に関連して異常な rGI 值の産生 (Dysglobulinemia) が全身間葉病变をお こすと唱へ Klemperer はかかる異常蛋白が無定型な結 合織の基礎物質中に漏出し，沈降して 発症すると想定 し，岡林（1961）は寋験的に卵白による遷延感作により Dysgamma Gl と共に結合織の系統的な 変性扣よび代 謝障害性病变を作成することに成功したと逨べている。 これらは病理学的所見の解釈には極めて都合がよいが,

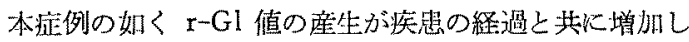

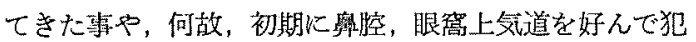
すか，锐明されない処も少くない。

後者に関してはWilliams \& Hochfilzer (1950) は壊

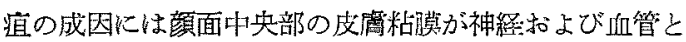
特に密接な関係を有することが開連するといら考古から 説明しているか゚全てがこれで解決されないと思和れる。

Moore, Bread (1950), Blatt et al (1959) b它成 因として Hypersensitivity reaction 等視した。彼 等はこれは一輴の抗原，抗体反応であり絬局抗原として

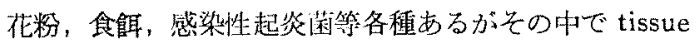
autoantigen を最も重視すべきであるとしている。即 占上符道に和ける始めの化学的, 理学们万至は感染的影

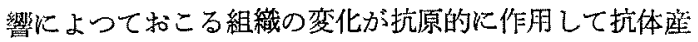
生を招き，それ等の相互作用が覀循環的に連鎖反応とな

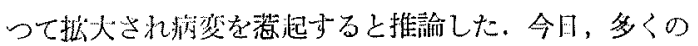

等者が免揬機構の翼常がこのような症状をさたすと考克 ている.

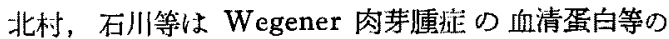
多化について唡討, RA-test 陽性.

fast moving I-Gl 值の增加が骖断上の重要な所見で あると述べ、こ扎りり rheumatoid factor の産生を認

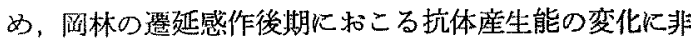
常に類似した状態 (dysimmune) にあると思われると 赫告しているが，その抗体に関しては不明であるとして Wる.

細菌，ウイルス学的にも未だ根拠となる所見の報告は ない.

結核との関連については前述の如く替否両論がある。 本症例る発病 1 年前胕結核の治療をらけているがその真 偽叔よび Wegener 肉芽尰と関連あつたか否か不明であ љ.

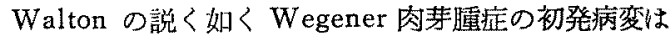
polyarteritis nodosa でなくて不明の因子による気道 の潰瘍であり，その後，経過と共にあたかる hypersensitivity reaction の如く全身的病变をお安上らに考 えられる。

\section{予後および治療について}

Wegener 肉芽尰は malignant granuloma に比して その経過は短く，死亡率は共に極めて高い。

転㷌は一般に激烈な過程をとる場合が多いが Evans の報告するように 4 年半も絽過する場合もあり，一方 malignant granuloma と考えられる症例でる，その維 滑が早い助合がある。

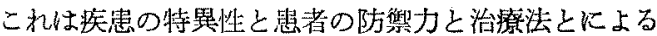
ためと考えられる。

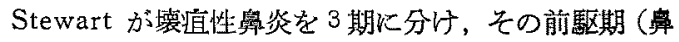
閉，舅漏等を主症状とする），活動期（勗症状覀化，血 性膿汁)，末期（全身㔛搦，高熱，出向が続き，顔面，鼻， 口蓋の組織欠損がひどくなる〉としているが，この事は 或程度 Wegener Granulomatosis にb当て嵌ると思わ れる、ただ，Stewartによれば，前駆期は4年位の事 もあるといら製であるが Walton の報告にすみられる 上5に Wegener 肉芽逼庭の㙞合は，この前駆期に当 る期間がかなり短かいようである。

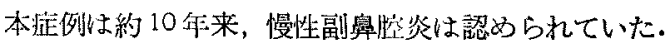
加発提は恐らく，死亡前 10 力月～1年 6 力月と考方ら れる。

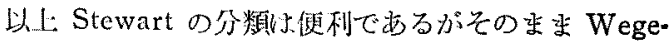




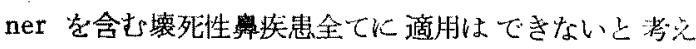
\%.

文献上 Wegener 肉芽腫に対する治療は，ステロイ ト療法， purine antagonists の使用，执上び放射線滰 法であるが，ての非でステロイド療法，拉上び放射線撩 法加比較的有效である事が知られている. Walton は少 量の深部療法が最もよいと述へている。

北村は，ステロイドホルモン有好妵例のあることを認 め手術，抗生剂は然效としている。広戸け自家ワタチン の併用をすすかている。

私共は本症例に批いて，ステロイド投与、コバルト照 射，抗生斉投与，制癌凩の投与，自家ワクチン（奥腔内 痂皮の staphylococcus aureus より作成）の投与等を 行つたが，その中では，ステロイドホルモン，コバルト 照射，エンドキサンの投与が此較的有効であつた。

ステロイドホルモンは，眼球突出，発蓺，全身状態悪 化に刘して，かなり症状を改善した。コバルト照射は眼 球突出に対して極好有効であり，左側の視力口恢復を みた。

たた竻野の陰影に対しては，その抬大を防ぐ程度で隍 影减少の效果は得られなかった。

Virus は検出し得ず，自家ワクチンは，殆んど効果を 認めなかつた。

抗生剂に関しては疾患の本態に詨しての効果は不明で あるが，該疾患は，その免度機構の障言か，副腎ホルモ ンの長期投与の結果か，極めて二次感染を来し易い故， 使用せさるを得ないと思う。

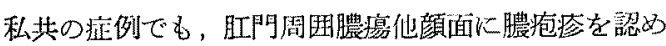
$\gamma=$

手術療法に関しては典型的肉芽運症の場台怯考元られ

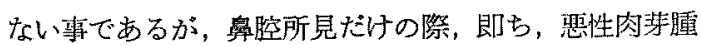
と似た臨床所見の頃に，これを行えばといら望みを抱く が㬰際上は不可能と思われるし，文献上の治療せしめた 報告を認めていない。

\section{結語}

1.37才の男子の Wegener 肉芽蕾症例を郝告した。

2. 患者は発症後約 1 年で呼吸困難夌きたし死しし た.

3. 臨床所見として眼球突出，學腔内の瘀皮形成，発

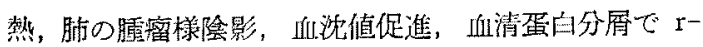
Gl.の著るしい上帠を認めた。

4. 剖検により上気道を主とする肉芽形成，抯管炎据 変を認如た。

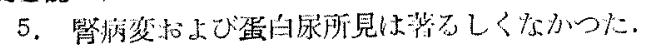

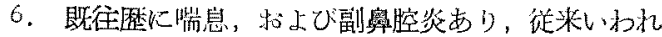
ていた。これらとの関逨につき㫴感すべき必要のあるこ とを感した。

7、房剔術をら怗ているがこれとの関係括よび，年 令，胸腺リンバ腺との周連については文献飞を，余り記

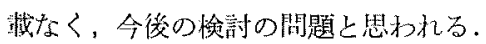

8）治療は放射線治登（コメ゙ルト照射）扣よびステロ イドの舆期使用，制癌成投与等を行つたが，いつれも， 刘应的には，かなり有效であつた。

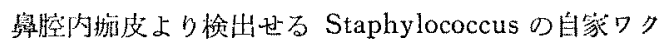
チンは殆んど然効であつた。

\section{锖考文献}

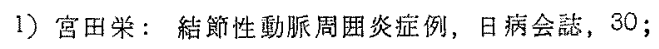
690,1940 (昭15)。 2) 今半一雄: 諸腈器のアレル

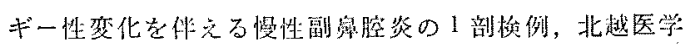

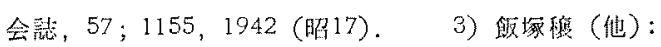

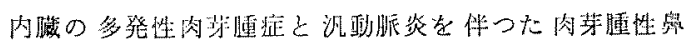

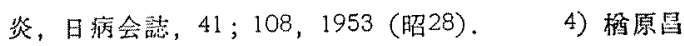

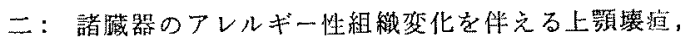

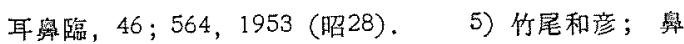
因性の悪敗血症, 山口医学，6;3，332，1957 (昭32). 6) 野村益世 (他): Wegener 肉芽腫症, 最新医学, $14 ， 2249 ， 1959$ (昭34). 7) 野田茂寿（他）：Wegner 肉茅尰症と考光られた一剖検例, 医学のあゆみ、 $38 ; 3,119,1961$ (昭36). 8) 小形岳三郎：Wegener 肉芽腫症の 2 剖検例，日病会誌，50；3，413， 1961 (昭36).9）滰野紧一（他）：㖽声を主垀とし

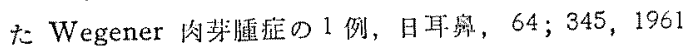

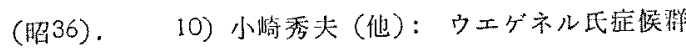
の一剖浼例, 日耳學, 64;1040, 1961 (昭36). 茂木五郎：Wegener 肉芽腫聇例，日耳率，65; 1373， 1962 (昭37). 12) 石會武堆 (他)：Wegener 氏肉

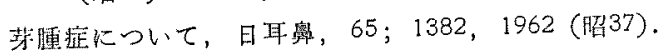
13) 福永算（他）: Fulminating Granulomatosis と䍐 われる!剖换例，医学のあゆみ、 40；409，1962(昭37). 14) Case reports of the Massachusetts General

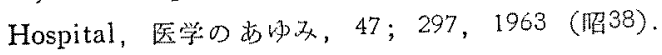

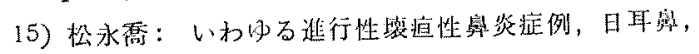
$66 ; 3,463,1963$ (炤38). 16) 小川筑二 (他):

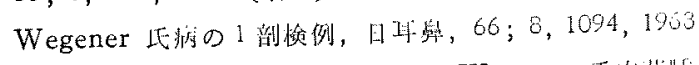

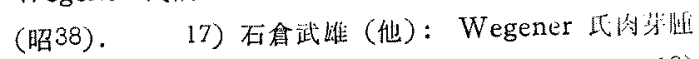

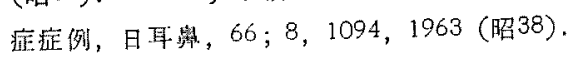

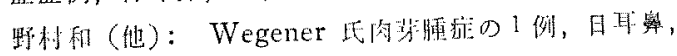


$66 ; 10,1309,1963$ (昭38). 19) 広戸幾一郎（他）:

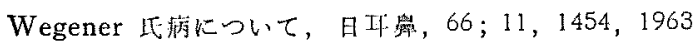

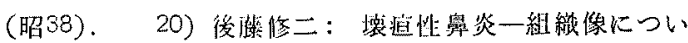
て一, 山耳舅, 67；4，664，1964（吼34). 21）伏見

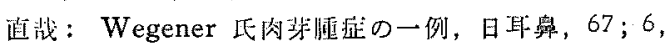
940.1964 (昭39)。22) 野中康弘（他）：Wegener

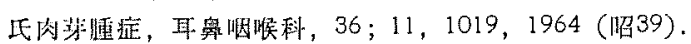

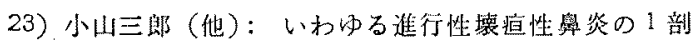

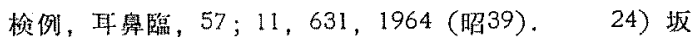

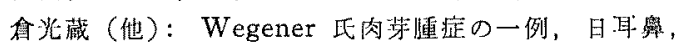
$68 ； 2 ， 204 ， 1965($ 昭40)，25）不川哮：Wegener 氏肉芽嗹症およびその類似疾患の血清学的研究，日耳 鼻，68；4，513，1965 (昭40). 26) F. Wegener: Über generalisierte, septische Gefässerkrankungen Verhandl. d. deutsch. path. Gesellsch. 29; 202, 1936. 27) R. Rössle: Über d!e Veränderungen der Schleimhäute der Neben-hohlen des Kopfes durch rheumatische Gefässentzündungen, Archiv. fur Ohren-Nasen-u. Kehlkopf. 142; 193, 1937. 28) F. Wegener: Uber eine eigenartige rhinogene Granulomatose, Beitr. Path. Anat. 102; 36, 1939.

29) J. Schmalix: Heilung eines Granuloma gangrenescens, Archiv. Ohren-Nasen-u. Kehlkopfheil 153; 297, 1943. 30) H.L. Williams: lethal granulomatous ulceration involving the midline facial tissues, Ann. Otol. 58; 1013, 1949. 31) G.C. Goldman and J. Churg: Wegener's granulomatosis, Archiv. of Path. 58; 533, $1954 . \quad$ 32) J.L. Fahey and J. Churg: Wegener's granulomatosis, The Amer. J. of Med. 17; 168, $1954 . \quad 33)$ E.W. Walton: Giant-cell granuloma of the respiratory tract, Brit. Med. Journal. 2; 265; 5087, 1954. 34) I.M. Blatt: Fatal granulomatosis of the respiratory tract, Archiv. of Oto. 70; 707, 1959.

E.W. Walton: Non-healing granulomata of the nose, J. Laryng. and Oto. 73; 242, 1959.

E.W. Walton: Reticulo-endothelial sarcoma arising in the nose and palate, J. Clin. Path. 13; 279, 1960. 37) C.P. Mills: Malignant granulomas of the nose and paranasal sinuses, J. Laryngo, and Oto. $72: 849,1958 . \quad 38)$ Amer. J. Med. Wegener's granulomatosis, $35 ; 384,1963 . \quad 39)$ Berman, D.A. et al: Wegener's granulomatosis, Ann. Inter, Med. 59; 521, 1963. 40) Mills. C.P.: The clinical diagnosis of malignant granulomata and Wegener's granulomatosis, Proc. Roya. Soc. Med. 57; 297, 1964 .

41) Kochsiek et al: Observation on the course of Wegener's granulomatosis, Med. Welt. 15; 842, 1964. 42) Duperrat B. et al: Cutaneous form of Wegener's granulomatosis, Bull. Soc. Franc. Derm. Syph. 71 ; 345, 1964 . 45) Schwartz A. et al: Wegener's granulomatosis, Acta Univ. Carol (Med.) (Praha). 9; 27, 1963. 44) Mc Gregor M.B. et al: Wegener's granulomatosis, Brit. J. Radiol. 37 ; 430, 1964, 45) Aston K.E., Lidholm S.O.: Extensive intracranial lesions in a case of orbital non-specific granuloma combined with polyartheritis nodosa, J. Clin. Path. 16; 137, 1963. 46) Dracham D.A.: Neurological complications of Wegener's granulomatosis, Archiv. Neurol. 8; 145, 1963. 47) Evans D.W. Hally J.B.: Wegener's granulomatosis, report of a patient surviving four and half years, J. Clin. Path. 16; 215, 1963.48 ) Friend D.S.: Wegener's granulomatosis, a case report, Archiv. Inter. Med. (Chicago) 3; 703, 1963. 49) Hunstein W., et al: On a case of Wegener's granulomatosis diagnosed during life, Deutch. Med. Wschr. 88; 52, $1963 . \quad 50)$ Iri H., Kameya S.: 2 autopsy cases of Wegener's granulomatosis, Jap. Clin. Path. 11 ; 160, 1963. 51) Mc Crea P.C. et al: Two unusual cases of giant cell myocarditis associated with mitral stenosis and with Wegener's syndrome, Brit. Heart J. 26; 490, 1964. 52) Lynch E.C. et al: Pulmonary cavitation in Wegener's granulomatosis, Amer. J. Rontzen. 92; 521, 1964. 53) C.Y. Yarington et al: Wegener's granulomatosis, Laryngoscope. 2; 259, 1965.

(翏原病，結合織アレルギ一等に関する文敬)

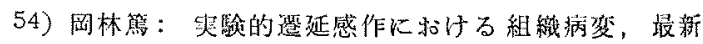
医学，16；1816，1961（昭36）。 55）堂野而維摩组 (他)：結合織アレルギー，最新医学，16；7，1824,

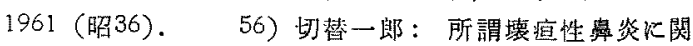
する諸問題，綘合医学，16.619，1959（昭34）。 57)

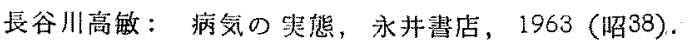

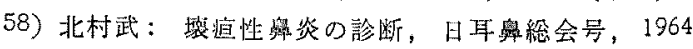

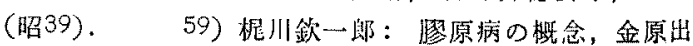
收, 1964 (明39). 60) P. Klemperer: The concept of collagen disease, Am. J. Path. 26; 502, 1950. 61) Ehrlich W.E.: Nature of collagen diseases, Am. Heart Journal. 43; 121, 1952.

稿を䅂るにあたり，恩所長谷川高敏教授の御 指導と御校閧を梁詂致します。

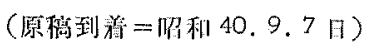

